\title{
The Effect of Legume Species Grown as Cover Crops in Olive Orchards on Soil Phosphorus Bioavailability
}

\author{
Margarida Arrobas, Ana Marília Claro, Isabel Q. Ferreira \& M. Ângelo \\ Rodrigues
}

To cite this article: Margarida Arrobas, Ana Marília Claro, Isabel Q. Ferreira \& M. Ângelo Rodrigues (2015) The Effect of Legume Species Grown as Cover Crops in Olive Orchards on Soil Phosphorus Bioavailability, Journal of Plant Nutrition, 38:14, 2294-2311, DOI: 10.1080/01904167.2015.1009104

To link to this article: http://dx.doi.org/10.1080/01904167.2015.1009104

Accepted author version posted online: 20

Feb 2015.

Published online: 20 Feb 2015.

Submit your article to this journal $₫$

Џ Article views: 121

Q View related articles $\sqsubset$

View Crossmark data 5 


\title{
THE EFFECT OF LEGUME SPECIES GROWN AS COVER CROPS IN OLIVE ORCHARDS ON SOIL PHOSPHORUS BIOAVAILABILITY
}

\author{
Margarida Arrobas, Ana Marília Claro, Isabel Q. Ferreira, \\ and M. Ângelo Rodrigues \\ Mountain Research Center, Polytechnic Institute of Braganç, Braganç, Portugal
}

\begin{abstract}
$\square \quad$ Some legume species are able to utilize phosphorus $(P)$ from sparingly soluble P sources benefiting companion crops or those following in the rotation. Lupinus albus, Vicia villosa, and a mixture of eleven annual pasture legumes were used in olive orchards as mulched cover crops as a means of increasing the soil $P$ availability. By soil testing and growing bioindicator P plants in the next season, it was possible to detect a slight but consistent increase in soil $P$ availability. The results indicated that the increase in soil $P$ availability was mainly due to the mineralization of the high $P$ content legume residues, rather than the direct effect in the rhizosphere of the living plants. The results also suggested that the good adaptation of white lupine to low $P$ environments might be due to a high internal P use efficiency of this species, producing high dry matter yields with low $P$ concentration in their tissues.
\end{abstract}

Keywords: lupine, hairy vetch, soil P availability, in situ soil incubation, olive grove, cover cropping

\section{INTRODUCTION}

The production costs of the traditional olive oil sector in the Mediterranean basin need to be reduced to maintain the farmers' profit in the face of stagnating olive oil prices. In addition, the reduction in production factors is also a way of mitigating the environmental impact of agricultural activities. Fertilizers are off-farm resources whose prices have increased day by day and whose ecological implications are not negligible due to the high energy consumption in their manufacture and the possible environmental contamination from their use (Gilliam et al., 1985; Werner, 2010).

The most common strategy to reduce the cost and the environmental damage of synthetic fertilizers has been the cultivation of pulses as main crops

Received 25 January 2013; accepted 5 March 2014.

Address correspondence to Margarida Arrobas, Mountain Research Center, Polytechnic Institute of Bragança, Campus de Santa Apolónia, Ap. 1152, 5301-855 Bragança, Portugal. E-mail: marrobas@ipb.pt 
in the rotations or the use of legume species as green manures. Legumes are able to access atmospheric dinitrogen $\left(\mathrm{N}_{2}\right)$ afforded by the ability to establish symbiotic relationships with nitrogen-fixing organisms living in their roots. Nitrogen (N) fixed by Rhizobium bacteria is used by the host legume plants in their own growth, being also transferred to companion non-legume species growing in mixtures (Ledgard, 1991; Walley et al., 1996), or used by the crops that follow them in the rotation (Jensen et al., 2004; Varennes et al., 2007; Carranca et al., 2009). In addition to their value as food or feed, legumes are also usually seen as a good method of increasing the soil fertility and reducing the environmental impact created by the over-use of synthetic fertilizers.

Some legume species, in addition to their role in $\mathrm{N}$ fixation, appear also to be efficient in using phosphorus (P) from soils where $\mathrm{P}$ is only sparingly available to most plants. The interest in these species has increased tremendously, since they can easily grow without $\mathrm{N}$ and $\mathrm{P}$ fertilizers, also benefiting companion crops or those that follow them in the rotation. White lupine seems to be one of those plants. In soils low in available $\mathrm{P}$, white lupine develops proteoid roots, or cluster roots, providing enhanced zones for $\mathrm{P}$ uptake coupled with the exudation of organic acids to the rhizosphere, which reduces $\mathrm{pH}$ and solubilizes $\mathrm{P}$ from stable $\mathrm{P}$ pools (Braum and Helmke, 1995; Bolland, 1997; Uhde-Stone et al., 2003; Watt and Evans, 2003; Zhu et al., 2005; Le Bayon et al., 2006; Schulze et al., 2006; Sepehr et al., 2012). Cu et al. (2005) have demonstrated that intercropping of wheat with white lupine results in increased wheat growth and $\mathrm{P}$ uptake due to the ability of white lupine to mobilize $\mathrm{P}$ from a citric acid soluble soil $\mathrm{P}$ pool not normally available to wheat. Other studies have showed an increase in growth, tissue $\mathrm{P}$ concentration, and shoot $\mathrm{P}$ content of wheat when grown after legumes, in comparison with when grown after wheat (Nuruzzaman et al., 2005a, 2005b).

Phosphorus is a macronutrient regularly applied as a fertilizer in most agricultural crops (Havlin et al., 2005). It is estimated that $\mathrm{P}$ availability to plant roots is limited in nearly two thirds of the cultivated soils in the world, causing an important constraint to crop production (Batjes, 1997). In addition, $\mathrm{P}$ is an element whose price is expected to greatly increase in the near future since phosphate fertilizers are derived from phosphate rocks, a finite resource worldwide which will disappear within the century (Gilbert, 2009; Hawkesford et al., 2012). The low availability of $\mathrm{P}$ in most soils and the increasing scarcity of phosphate rocks is causing the scientific community to seek alternatives such as the use of the indigenous soil $\mathrm{P}$ pools more efficiently. The plants efficient in utilizing sparingly soluble soil $\mathrm{P}$ have been receiving great attention from the scientific community, particularly in the last two decades (Braum and Helmke, 1995; Veneklaas et al., 2003; Watt and Evans, 2003; Tomasi et al., 2008; Wang et al., 2010, 2011; Sepehr et al., 2012). 
This study aims to evaluate the ability of various legume species to increase soil $\mathrm{P}$ availability when they are grown as cover crops in traditional olive groves. The effect of the legume cover crops to mobilize $\mathrm{P}$ was determined from four different methodological approaches: i) determination of $\mathrm{P}$ concentration and $\mathrm{P}$ content in above-ground biomass of legume cover crops; ii) analysis of the P nutritional status of the olive trees; iii) monitoring the soil $\mathrm{P}$ availability in the year following the growth of the legume species by using an in situ incubation technique;, and iv) growing herbaceous plants as indicators of soil $\mathrm{P}$ bioavailability in the year after the legume species had been grown. The native vegetation that developed in the soil was also sampled during the winter and spring as an indicator of soil $\mathrm{P}$ bioavailability.

\section{MATERIALS AND METHODS}

\section{Characterization of the Experimental Sites}

The field experiments were carried out in two olive orchards located in Suçães, Mirandela $\left(41^{\circ} 29^{\prime} \mathrm{N}, 7^{\circ} 15^{\prime} \mathrm{W}\right)$ and Carrascal, Vila Flor $\left(41^{\circ} 16^{\prime} \mathrm{N}\right.$, $\left.7^{\circ} 5^{\prime} \mathrm{W}\right)$ in NE Portugal.

The orchard of Suçães was 20 years old when the trial started in September 2009. The trees are of cv. Cobrançosa and planted $7 \times 7 \mathrm{~m}$. Before the trial started, the farmer used to control the weeds through the application of a glyphosate-based herbicide early in May. The orchard was planted in a Leptosol of a sandy loam (13.1\% clay, $26.6 \%$ silt, $60.3 \%$ sand) texture, $\mathrm{pH}$ (water; $\left.\mathrm{H}_{2} \mathrm{O}\right)$ 4.1, organic carbon $7.9 \mathrm{~g} \mathrm{~kg}^{-1}$ and extractable $\mathrm{P}$ and potassium (K) (Égner-Riehm method) 21.0 and $96.3 \mathrm{mg} \mathrm{kg}^{-1}$, respectively. Shortly before the trial started, $1500 \mathrm{~kg} \mathrm{ha}^{-1}$ of lime $\left[88 \%\right.$ calcium carbonate $\left(\mathrm{CaCO}_{3}\right)$ and $5 \%$ magnesium carbonate $\left.\left(\mathrm{MgCO}_{3}\right)\right]$ and $250 \mathrm{~kg} \mathrm{ha}^{-1}$ of superphosphate [18\% phosphorus pentoxide $\left.\left(\mathrm{P}_{2} \mathrm{O}_{5}\right)\right]$ were applied.

The orchard of Carrascal was 15 years old of cv. 'Negrinha de Freixo' and the trees were spaced $7 \times 7 \mathrm{~m}$. Before the trial started, the weeds were controlled by tillage. The orchard is also planted in a Leptosol of a sandy loam $\left(11.8 \%\right.$ clay, $32.0 \%$ silt, $56.2 \%$ sand) texture, $\mathrm{pH}\left(\mathrm{H}_{2} \mathrm{O}\right) 5.7$, organic carbon $8.3 \mathrm{~g} \mathrm{~kg}^{-1}$ and extractable $\mathrm{P}$ and $\mathrm{K} 33.2$ and $41.5 \mathrm{mg} \mathrm{kg}^{-1}$, respectively.

\section{Experimental Designs}

The experiment of Suçães included three different ground-cover treatments: white lupine; a mixture of self-reseeding annual legumes; and natural vegetation (control plot). The mixture of pasture legumes consisted of eleven species/varieties, namely: Ornithopus compressus L. cv. 'Charano'; Ornithopus sativus Brot. cvs. 'Erica' and 'Margurita'; Trifolium subterraneum L. ssp subterraneum Katzn. and Morley cvs. 'Dalkeith', 'Seaton Park', 'Denmark', and 'Nungarin'; Trifolium resupinatum L. ssp resupinatum Gib and Belli 
cv. 'Prolific'; Trifolium incarnatum L. cv. 'Contea'; Trifolium michelianum Savi cv. 'Frontier'; and Biserrula pelecinus L. cv. 'Mauro'. The areas of the plots were 0.4 ha. Small plots $\left(150 \mathrm{~m}^{2}\right)$ of oats (Avena sativa L.) were also included in the field trials to allow the comparison of $\mathrm{P}$ recovery of legume and non-legume species. The seed rates were 180, 30 and $150 \mathrm{~kg}$ seed ha $\mathrm{ha}^{-1}$, respectively, for white lupine, pasture legumes and oats. Each individual species of the mixture of the pasture legumes was sown at an approximate rate of an eleventh of that recommended if seeded alone in pure culture.

The experiment of Carrascal included three cover cropping treatments similar to those described to Suçães, plus a further treatment consisting of hairy vetch (Vicia villosa Roth.). The areas of the plots were 0.6 ha and the seed rate of hairy vetch $30 \mathrm{~kg}$ seed $\mathrm{ha}^{-1}$.

\section{Dry Matter Yield and Tissue Analysis}

On 6 May 2010, the dry matter (DM) yields of cover crops in both the experiments were determined after sampling in four replications the phytomass by using a square meter grid. After it had been cut, the phytomass was oven-dried at $70^{\circ} \mathrm{C}$, weighed, and ground. Tissue $\mathrm{P}$ concentration was determined after microwave-assisted acid digestion (nitric acid; $\mathrm{HNO}_{3}$ ) in a closed vessel. Phosphorus in the extracts was determined colorimetrically by the blue molybdate method using ascorbic acid as the reducing agent (Walinga et al., 1997).

After recovering the samples for analysis, the phytomass was destroyed with a rotary slasher and left on the ground as a mulch.

\section{Herbaceous Vegetation as Indicators of Soil P Bioavailability}

In the year after the growth of the legume cover crops, two herbaceous species were sown in Suçães and Carrascal olive orchards and P content used as an indicator of soil $\mathrm{P}$ bioavailability. The species used were turnip, which presents a peak of growth in the autumn, and barley, presenting a major peak of growth in the spring. The methodology was an adaptation of that developed by Rodrigues et al. (2010) to study the $\mathrm{N}$ dynamic in a pasture. The combined action of these two species allows the monitoring of $\mathrm{P}$ availability in the soil in the year after the legume cover crops had been mulched. Ten seeds of each species were sown in October 2010 within polyvinyl chloride (PVC) rings of $154 \mathrm{~mm}$ diameter and $2 \mathrm{~cm}$ height. The PVC rings provided some protection from natural vegetation developing outside the rings. To obtain a standardized sample, the micro-plots were weeded of unsown vegetation. Each species was sown in six replications per ground-cover treatment. The turnip plants were cut on 24 November 2010 and barley on 16 May 2011. The biomass yielded within the PVC rings was cut, oven-dried 
at $70^{\circ} \mathrm{C}$, weighed, ground, and analyzed for $\mathrm{P}$ concentration. Shoot $\mathrm{P}$ content was estimated, taking into account the DM yield and $\mathrm{P}$ concentration in the plant tissues. The $\mathrm{P}$ content in the natural vegetation developing in the year after the growth of the legume cover crops was determined on three different dates during winter and spring 2011 (Suçães, 28 February, 11 April and 2 May; Carrascal, 28 February, 18 March, and 2 May). The biomass was sampled in four replications per treatment using a square meter grid. The samples were also dried, weighed, ground, and analyzed for $\mathrm{P}$ concentration.

\section{In Situ Incubation}

Shortly after the legume cover crops had been mulched, an in situ incubation technique was started, being carried out for a year. The incubation technique consists of burying metallic tubes by hammering them into the soil and leaving them there for approximately monthly periods. This kind of methodology is frequently used to measure the $\mathrm{N}$ dynamic in agriculture and forestry soils (Raison et al., 1987; Subler et al., 1995; Durán et al., 2012). After they had been buried, the tubes were capped with a piece of tile to prevent the entry of rainwater, and the direct incidence of sunlight on the metal, which would modify the thermal regime of the incubating soil cores. At the beginning of each new incubation period, fresh soil samples (not incubated) were also taken to allow the estimation of $\mathrm{P}$ release from the mineralization of legume cover crop residues, by comparing soil P levels in incubated samples (in the absence of $\mathrm{P}$ uptake by vegetation) in time $t$, with $P$ levels in fresh samples in time.

Fresh and incubated samples were analyzed for extractable P by using two standard laboratory methods usually used in routine P-fertilizer recommendation programs. The Égner-Riehm method consists of shaking $2.5 \mathrm{~g}$ soil with $50 \mathrm{~mL}$ ammonium lactate-acetic acid $3.5 \mathrm{M}$ solution buffered at $\mathrm{pH}$ 3.75 for 2 hours (Égner et al., 1960). The Olsen method consists of shaking $2.5 \mathrm{~g}$ soil with $50 \mathrm{~mL} 0.5 \mathrm{M}$ sodium bicarbonate solution, brought to $\mathrm{pH} 8.5$ with $5 \mathrm{~N}$ sodium hydroxide, for 30 minutes (Olsen et al., 1954).

\section{Statistical Analysis}

Data analysis was carried out using JMP software (SAS Institute, Cary, NC, USA). A completely randomized design with a single factor (legume cover crops) was used to compare the population means (Ott and Lognecker, 2001) regarding DM yield, $P$ concentration, and $P$ content. After analysis of variance (ANOVA), the means with significant differences $(P<0.05)$ were separated by the Tukey HSD test $(\alpha=0.05)$. 
TABLE 1 Dry matter yield, $\mathrm{P}$ concentration and $\mathrm{P}$ content in aboveground biomass of cover crops grown in Suçães and Carrascal olive orchards

\begin{tabular}{|c|c|c|c|c|c|c|}
\hline & \multicolumn{3}{|c|}{ Suçães } & \multicolumn{3}{|c|}{ Carrascal } \\
\hline & $\begin{array}{l}\text { DM yield } \\
\mathrm{Mg} \mathrm{ha}^{-1}\end{array}$ & $\begin{array}{l}\text { P conc. } \\
\mathrm{g} \mathrm{kg}^{-1}\end{array}$ & $\begin{array}{l}\text { P content } \\
\mathrm{kg} \mathrm{ha}^{-1}\end{array}$ & $\begin{array}{l}\text { DM yield } \\
\mathrm{Mg} \mathrm{ha}^{-1}\end{array}$ & $\begin{array}{l}\text { P conc. } \\
\mathrm{g} \mathrm{kg}^{-1}\end{array}$ & $\begin{array}{l}\text { P content } \\
\mathrm{kg} \mathrm{ha}^{-1}\end{array}$ \\
\hline White lupine & $8.20 \mathrm{a}^{1}$ & $0.58 \mathrm{c}$ & $4.78 \mathrm{a}$ & $6.87 \mathrm{a}$ & $1.14 \mathrm{c}$ & 7.83ab \\
\hline Pasture legs & $6.45 \mathrm{~b}$ & $0.98 \mathrm{bc}$ & $6.37 \mathrm{a}$ & $5.61 \mathrm{a}$ & $1.22 \mathrm{c}$ & 7.07ab \\
\hline Vetch & - & - & - & $5.94 \mathrm{a}$ & $1.95 \mathrm{~b}$ & $11.70 \mathrm{a}$ \\
\hline Nat veg & $0.68 \mathrm{~d}$ & $1.70 \mathrm{a}$ & $1.16 \mathrm{~b}$ & $1.14 \mathrm{~b}$ & $2.63 \mathrm{a}$ & $2.99 b$ \\
\hline Oats & $3.01 \mathrm{c}$ & $1.27 \mathrm{ab}$ & $3.83 \mathrm{ab}$ & $5.03 \mathrm{a}$ & $1.71 b c$ & $8.54 \mathrm{ab}$ \\
\hline
\end{tabular}

${ }^{1}$ Means followed by the same letter in columns are not different by Tukey'sw HSD test $(\alpha=0.05)$.

\section{RESULTS}

\section{Dry Matter Yield and P Recovery by Cover Crops}

Mean DM yields of legume cover crops were significantly higher than that of natural vegetation and oats, primarily due to their access to atmospheric $\mathrm{N}_{2}$. In the Suçães experiment, white lupine produced $8.20 \mathrm{~kg} \mathrm{DM} \mathrm{ha}{ }^{-1}$ whereas natural vegetation only $0.68 \mathrm{~kg} \mathrm{DM} \mathrm{ha}^{-1}$ (Table 1). However, natural vegetation showed significantly higher tissue $\mathrm{P}$ concentration than the cultivated cover crops. Phosphorus concentrations in white lupine tissues were particularly low. In Suçães, P concentrations in white lupine and natural vegetation tissues were respectively 0.58 and $1.70 \mathrm{~g} \mathrm{~kg}^{-1}$ and in Carrascal 1.14 and $2.63 \mathrm{~g} \mathrm{~kg}^{-1}$. Phosphorus content was significantly higher in legume species than in natural vegetation due to the great differences in DM yields. Oats showed P contents not statistically different to legume cover crops.

\section{Dry Matter Yield and P Recovery by Turnip, Barley and Natural Vegetation Grown after Mulching the Cover Crops}

Turnip DM yield was significantly higher in the plots previously cropped with white lupine than in the plots of the other ground-cover treatments. Dry matter yields of turnip recorded in natural vegetation plots were significantly lower than that found in the plots previously cropped with legumes (Table 2). Mean $\mathrm{P}$ concentrations in turnip tissues were the lowest from the natural vegetation plots in comparison with the plots of the legume cover crops, though the difference between means has only statistical significance in the Suçães experiment. Phosphorus content in turnip plants was significantly different among ground-cover treatments. The highest values were found from white lupine and hairy vetch plots.

In Suçães, barley DM yield was significantly higher in the plot previously cropped with pasture legumes than in white lupine and natural vegetation plots (Table 3). In Suçães, P concentration in barley tissues was significantly 
TABLE 2 Dry matter (DM) yield, P concentration and P content in aboveground biomass of turnip cultivated in circular micro-plots in the year after the growth of the legume cover crops in Suçães and Carrascal olive orchards

\begin{tabular}{lccccccc}
\hline & \multicolumn{3}{c}{ Suçães } & & \multicolumn{3}{c}{ Carrascal } \\
\cline { 2 - 4 } \cline { 6 - 8 } Treatment & $\begin{array}{c}\text { DM yield } \\
\mathrm{kg} \mathrm{ha}^{-1}\end{array}$ & $\begin{array}{c}\text { P conc. } \\
\mathrm{g} \mathrm{kg}^{-1}\end{array}$ & $\begin{array}{c}\text { P content } \\
\mathrm{kg} \mathrm{ha}^{-1}\end{array}$ & & $\begin{array}{c}\text { DM yield } \\
\mathrm{kg} \mathrm{ha}^{-1}\end{array}$ & $\begin{array}{c}\text { P conc. } \\
\mathrm{g} \mathrm{kg}^{-1}\end{array}$ & $\begin{array}{c}\text { P content } \\
\mathrm{kg} \mathrm{ha}^{-1}\end{array}$ \\
\hline White lupine & $961.0 \mathrm{a}^{1}$ & $2.64 \mathrm{ab}$ & $2.53 \mathrm{a}$ & & $1635.6 \mathrm{a}$ & $3.49 \mathrm{a}$ & $5.59 \mathrm{a}$ \\
Pasture legs & $316.8 \mathrm{~b}$ & $2.85 \mathrm{a}$ & $0.90 \mathrm{~b}$ & & $949.4 \mathrm{~b}$ & $3.59 \mathrm{a}$ & $3.41 \mathrm{ab}$ \\
Hairy vetch & - & - & - & & $702.6 \mathrm{~b}$ & $3.23 \mathrm{a}$ & $2.27 \mathrm{~b}$ \\
Nat veg & $206.9 \mathrm{c}$ & $2.09 \mathrm{~b}$ & $0.43 \mathrm{c}$ & & $173.5 \mathrm{c}$ & $3.13 \mathrm{a}$ & $0.54 \mathrm{c}$ \\
\hline
\end{tabular}

${ }^{1}$ Means followed by the same letter in columns are not different by Tukey's HSD test $(\alpha=0.05)$.

higher in the plants from pasture legume than that from white lupine and natural vegetation plots. Phosphorus content in barley plants of the Suçães experiment was significantly higher in the pasture legume plot, followed by white lupine and natural vegetation. In Carrascal, mean barley DM yields and $\mathrm{P}$ concentrations were not significantly different between the groundcover treatments. Phosphorus content was significantly lower in the natural vegetation plot in comparison with the plots of legume cover crops.

In Suçães, the natural vegetation that developed in the year following the establishment of the mulches of the ground-cover treatments was significantly higher in white lupine in comparison with the natural vegetation plot (Table 4). The biomass recorded in the pasture legume plot cannot be compared to that of the other plots, since it corresponds to the tissues of the pasture legume species that self-reseeded in the second growing season. In Carrascal, the DM yield recorded in the hairy vetch plot was significantly higher than that found in the white lupine plot. The lowest values were found in the natural vegetation plot. In Suçães, the mean $\mathrm{P}$ content reached the highest value in the pasture legume plot followed by white lupine and natural vegetation plots. In Carrascal, the higher mean $\mathrm{P}$ contents were found in

TABLE 3 Dry matter (DM) yield, P concentration and P content in aboveground biomass of barley cultivated in circular micro-plots in the year after the growth of the legume cover crops in Suçães and Carrascal olive orchards

\begin{tabular}{|c|c|c|c|c|c|c|}
\hline \multirow[b]{2}{*}{ Treatment } & \multicolumn{3}{|c|}{ Suçães } & \multicolumn{3}{|c|}{ Carrascal } \\
\hline & $\begin{array}{l}\text { DM yield } \\
\mathrm{kg} \mathrm{ha}^{-1}\end{array}$ & $\begin{array}{l}\mathrm{P} \text { conc. } \\
\mathrm{g} \mathrm{kg}^{-1}\end{array}$ & $\begin{array}{l}\text { P content } \\
\mathrm{kg} \mathrm{ha}^{-1}\end{array}$ & $\begin{array}{l}\text { DM yield } \\
\mathrm{kg} \mathrm{ha}^{-1}\end{array}$ & $\begin{array}{l}\mathrm{P} \text { conc. } \\
\mathrm{g} \mathrm{kg}^{-1}\end{array}$ & $\begin{array}{c}\text { P content } \\
\mathrm{kg} \mathrm{ha}^{-1}\end{array}$ \\
\hline White lupine & $336.8 b^{1}$ & $1.95 \mathrm{~b}$ & $0.66 \mathrm{~b}$ & $567.4 \mathrm{a}$ & $3.87 \mathrm{a}$ & $2.24 \mathrm{a}$ \\
\hline Pasture legs & $1098.8 \mathrm{a}$ & $2.63 \mathrm{a}$ & $3.05 \mathrm{a}$ & $463.2 \mathrm{a}$ & $4.79 \mathrm{a}$ & $2.20 \mathrm{a}$ \\
\hline Hairy vetch & - & - & - & $504.2 \mathrm{a}$ & $4.61 \mathrm{a}$ & $2.32 \mathrm{a}$ \\
\hline Nat veg & $180.6 \mathrm{c}$ & $1.57 \mathrm{~b}$ & $0.28 \mathrm{c}$ & $251.9 \mathrm{a}$ & $3.95 \mathrm{a}$ & $0.99 \mathrm{a}$ \\
\hline
\end{tabular}

\footnotetext{
${ }^{1}$ Means followed by the same letter in columns are not different by Tukey's HSD test $(\alpha=0.05)$.
} 
TABLE 4 Dry matter (DM) yield, P concentration and P content in aboveground biomass of natural vegetation developing in the year after the growth of the legume cover crops in Suçães and Carrascal olive orchards and sampled on 2 May 2011

\begin{tabular}{|c|c|c|c|c|c|c|}
\hline \multirow[b]{2}{*}{ Treatment } & \multicolumn{3}{|c|}{ Suçães } & \multicolumn{3}{|c|}{ Carrascal } \\
\hline & $\begin{array}{l}\text { DM yield } \\
\mathrm{kg} \mathrm{ha}^{-1}\end{array}$ & $\begin{array}{l}\text { P conc. } \\
\mathrm{g} \mathrm{kg}^{-1}\end{array}$ & $\begin{array}{l}\text { P content } \\
\mathrm{kg} \mathrm{ha}^{-1}\end{array}$ & $\begin{array}{c}\text { DM yield } \\
\mathrm{kg} \mathrm{ha}^{-1}\end{array}$ & $\begin{array}{l}\text { P conc. } \\
\mathrm{g} \mathrm{kg}^{-1}\end{array}$ & $\begin{array}{l}\text { P content } \\
\mathrm{kg} \mathrm{ha}^{-1}\end{array}$ \\
\hline White lupine & $1774.0 \mathrm{~b}^{1}$ & $1.44 \mathrm{ab}$ & $2.49 \mathrm{~b}$ & $1581.0 \mathrm{~b}$ & $2.64 \mathrm{a}$ & $4.27 \mathrm{~b}$ \\
\hline Pasture legs & $4082.1 \mathrm{a}$ & $1.24 \mathrm{~b}$ & $5.06 \mathrm{a}$ & $3532.8 \mathrm{a}$ & $2.47 \mathrm{a}$ & $8.53 a$ \\
\hline Hairy vetch & - & - & - & $2779.3 \mathrm{a}$ & $3.21 \mathrm{a}$ & $8.90 \mathrm{a}$ \\
\hline Nat veg & $445.4 \mathrm{c}$ & $1.98 \mathrm{a}$ & $0.86 c$ & $720.3 c$ & $2.89 \mathrm{a}$ & $2.18 \mathrm{c}$ \\
\hline
\end{tabular}

${ }^{1}$ Means followed by the same letter in columns are not different by Tukey's HSD test $(\alpha=0.05)$.

hairy vetch and pasture legume plots and the lower in the natural vegetation plot. On the other dates of sampling of natural vegetation (28 February, 18 March, and 11 April) the pattern of DM yield, $\mathrm{P}$ concentration, and $\mathrm{P}$ content was similar to that found on 2 May (data not shown).

\section{Effect of Cover Crops on P Nutritional Status of Olive Trees}

The ground-cover treatments had a modest effect on $\mathrm{P}$ concentrations in olive leaves (Table 5). The mean leaf $\mathrm{P}$ concentrations presented statistical differences only on a few occasions. On the sampling date of July 2010, leaf $\mathrm{P}$ concentration in hairy vetch plot was significantly higher than that found in the other ground-cover treatments. On the last leaf sampling date, on 2 January 2012, leaf $\mathrm{P}$ concentrations were the highest in pasture legume plots, in both the Suçães and Carrascal experiments.

TABLE 5 Phosphorus concentration in olive leaves on five sampling dates during and after the cultivation of legume cover crops in Suçães and Carrascal olive orchards

\begin{tabular}{lccccc}
\hline & 14 Jan. 2010 & 22 Jul. 2010 & 27 Jan. 2011 & 27 Jul. 2011 & 2 Jan. 2012 \\
\hline White lupine & $1.00 \mathrm{a}^{1}$ & $1.08 \mathrm{a}$ & $1.19 \mathrm{a}$ & $0.61 \mathrm{a}$ & $0.99 \mathrm{~b}$ \\
Pasture legs & $0.74 \mathrm{a}$ & $0.95 \mathrm{a}$ & $1.54 \mathrm{a}$ & $0.72 \mathrm{a}$ & $1.15 \mathrm{a}$ \\
Nat veg & $0.94 \mathrm{a}$ & $1.10 \mathrm{a}$ & $1.39 \mathrm{a}$ & $0.55 \mathrm{a}$ & $0.90 \mathrm{~b}$ \\
& & & & & \\
White lupine & $0.82 \mathrm{a}$ & $1.88 \mathrm{ab}$ & $1.76 \mathrm{a}$ & $1.46 \mathrm{a}$ & $1.58 \mathrm{~b}$ \\
Pasture legs & $0.88 \mathrm{a}$ & $1.66 \mathrm{bc}$ & $1.77 \mathrm{a}$ & $1.35 \mathrm{a}$ & $2.05 \mathrm{a}$ \\
Vetch & $1.18 \mathrm{a}$ & $2.08 \mathrm{a}$ & $2.13 \mathrm{a}$ & $1.45 \mathrm{a}$ & $1.90 \mathrm{ab}$ \\
Nat veg & $0.91 \mathrm{a}$ & $1.55 \mathrm{c}$ & $1.91 \mathrm{a}$ & $1.56 \mathrm{a}$ & $1.66 \mathrm{ab}$ \\
\hline
\end{tabular}

\footnotetext{
${ }^{1}$ Means followed by the same letter in columns, and for each location, are not different by Tukey's HSD test $(\alpha=0.05)$.
} 


\section{Soil Phosphorus Availability after Mulching the Cover Crops}

The determination of extractable soil $\mathrm{P}$ by the Égner-Riehm method from fresh soil samples did not detect any consistent effect of the legume cover crops in comparison with natural vegetation in the Suçães experiment (Figure 1a). From the incubated soil cores, it seems that a small peak of higher extractable $\mathrm{P}$ was observed early in the winter, but the results from the legume plots also did not show any significant difference to the natural vegetation plot (Figure 1b). Consequently, the net balance of $\mathrm{P}$ released, associated with the ground-cover treatments and determined by the ÉgnerRiehm method, was practically nil (Figure 1c).

The evaluation of soil $\mathrm{P}$ availability by the Olsen method using separately fresh (Figure 2a) and incubated (Figure 2b) soil cores did not show any detectable difference among the ground-cover treatments of the Suçães experiment. However, when the differences from incubated and fresh cores were taken into account (Figure 2c), the values of $\mathrm{P}$ released from the white lupine plot were higher than that obtained from pasture legumes and natural vegetation plots.

In the Carrascal experiment, and when the Égner-Riehm method was used, the effect of legume cover crops on the extractable soil $\mathrm{P}$ appeared clearly either from fresh (Figure 3a) and incubated (Figure 3b) soil cores and also from released $\mathrm{P}$ (Figure 3c). The soil cores from the plots of hairy vetch and white lupine released more $\mathrm{P}$ than soil cores from the other ground-cover treatments.

From the Carrascal experiment, consistent differences in soil extractable $\mathrm{P}$ determined by the Olsen method were observed among the ground-cover treatments (Figure 4). The result appeared particularly clearly from incubated soil cores and $\mathrm{P}$ released (Figure $4 \mathrm{~b}$ and $4 \mathrm{c}$ ). Accumulated $\mathrm{P}$ released from the hairy vetch plot was higher than that observed from the other treatments (Figure 4c).

\section{DISCUSSION}

The DM yields of legume cover crops were incomparably higher than that of oats and natural vegetation. Unequivocally, the primary reason would be the access of the legume species to atmospheric $\mathrm{N}_{2}$. Phosphorus concentration in natural vegetation was, however, significantly higher than that found in legume species. The main reason for that was probably a dilution effect on $\mathrm{P}$ concentration in legume tissues due to the tremendous increase in phytomass occurring in plants accessing atmospheric $\mathrm{N}_{2}$. Dilution and concentration effects of nutrients in plants are common phenomena (Jarrell and Beverly, 1981; Römheld, 2012), which can partially explain the low tissue $\mathrm{P}$ concentrations in the plants producing the higher yields. Phosphorus content was higher in legume species than in natural vegetation, which 

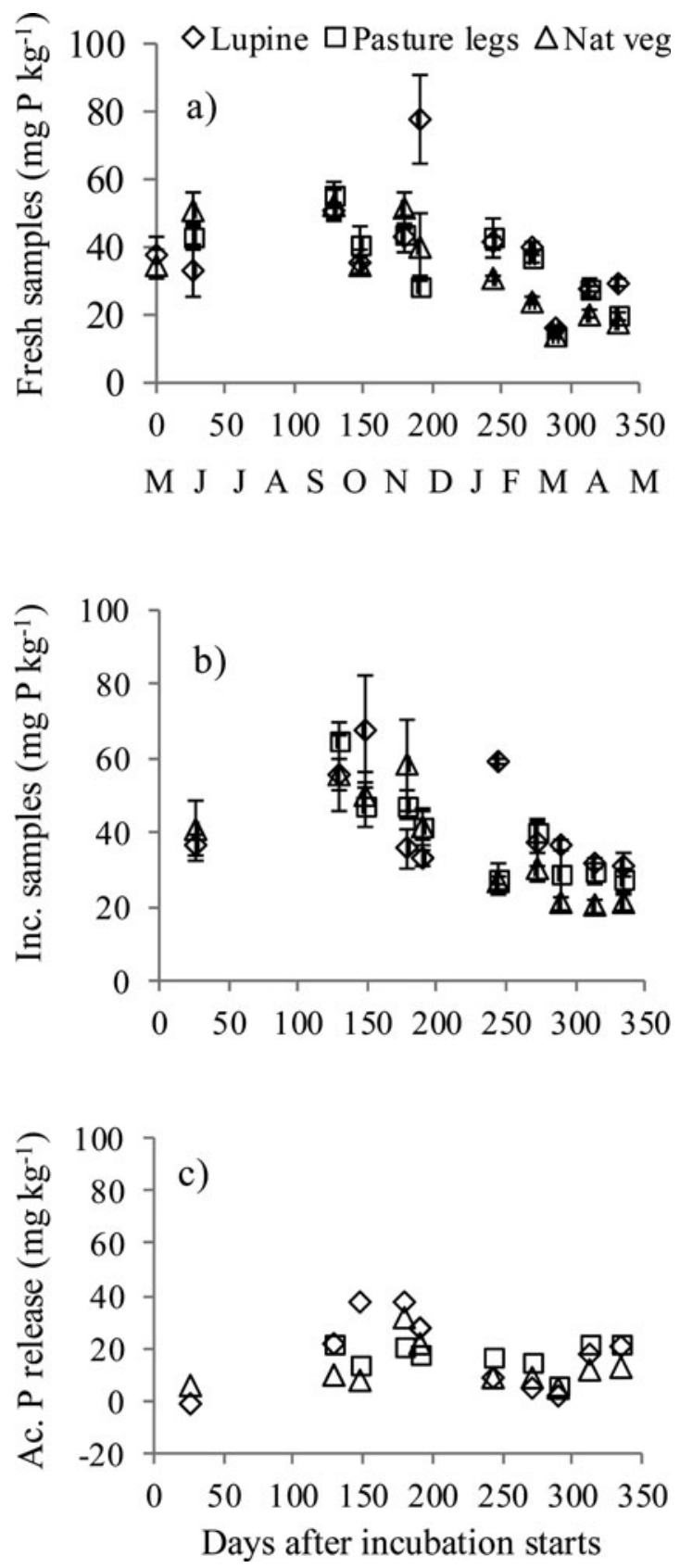

FIGURE 1 Extractable P in A) fresh and B) incubated soil cores determined by the Égner-Riehm method during the year after the growth of legume cover crops (May 2010 to May 2011) in Suçães olive orchard and $\mathrm{C}$ ) accumulated $\mathrm{P}$ release throughout the incubation experiment. The vertical bars represent the mean confidence limits $(\alpha=0.05)$. 

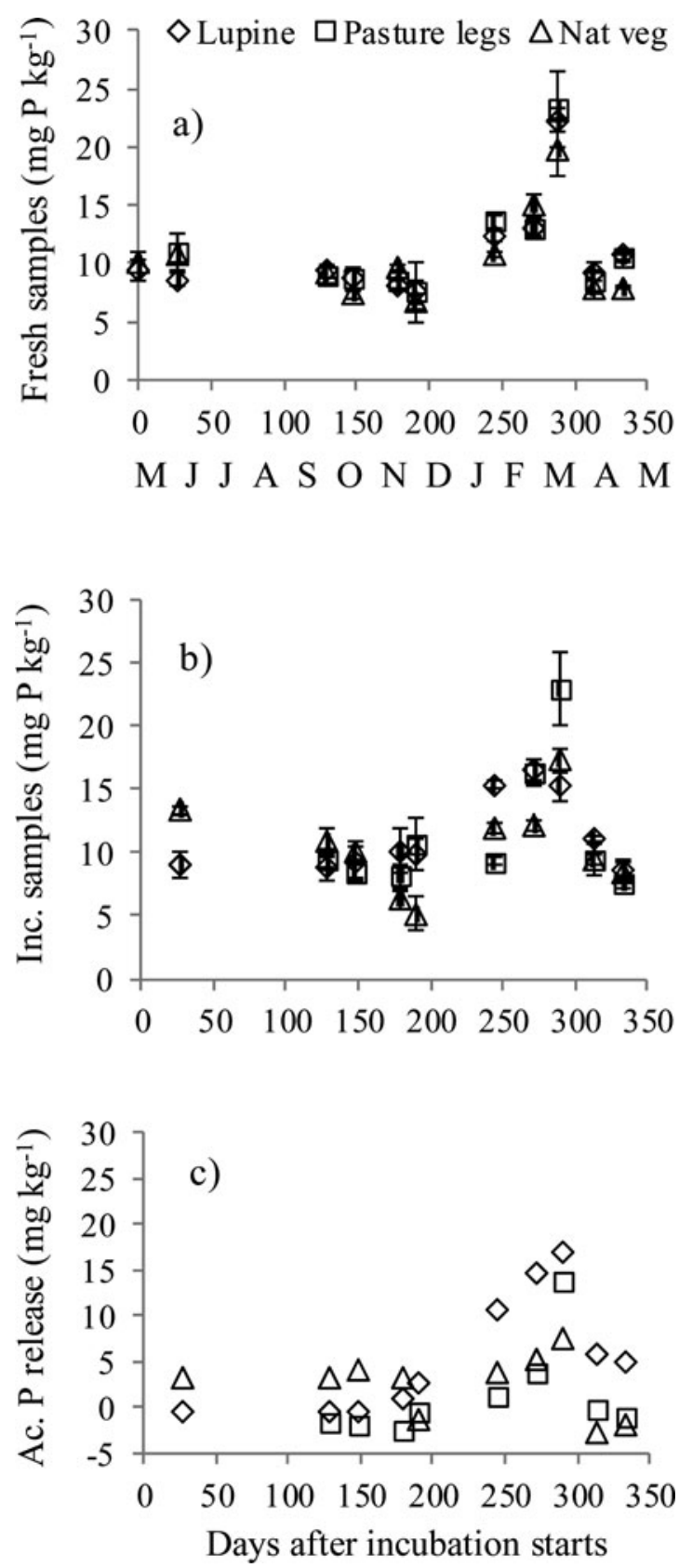

FIGURE 2 Extractable $\mathrm{P}$ in A) fresh and B) incubated soil cores determined by the Olsen method during the year after the growth of legume cover crops (May 2010 to May 2011) in Suçães olive orchard and $\mathrm{C}$ ) accumulated $\mathrm{P}$ release throughout the incubation experiment. The vertical bars represent the mean confidence limits $(\alpha=0.05)$. 

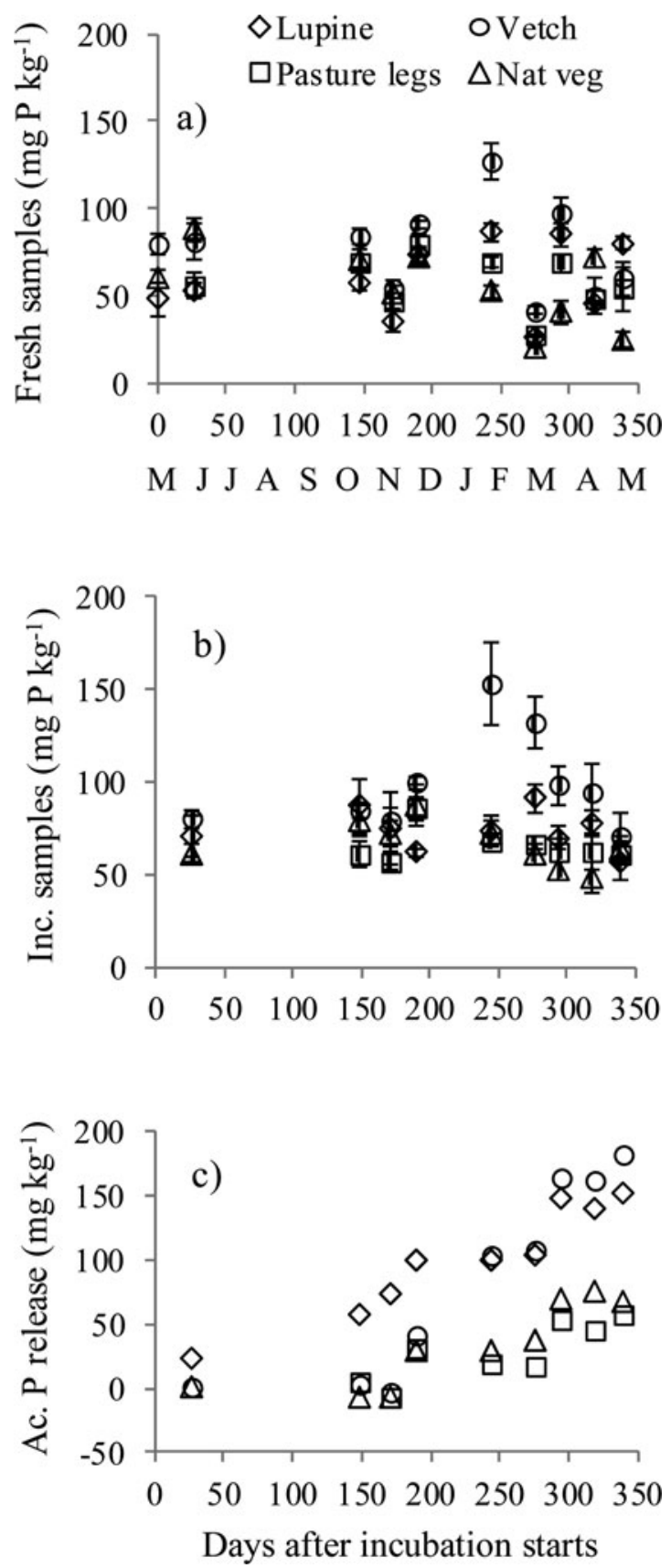

FIGURE 3 Extractable P in A) fresh and B) incubated soil cores determined by the Égner-Riehm method during the year after the growth of legume cover crops (May 2010 to May 2011) in Carrascal olive orchard and $\mathrm{C}$ ) accumulated $\mathrm{P}$ release throughout the incubation experiment. The vertical bars represent the mean confidence limits $(\alpha=0.05)$. 

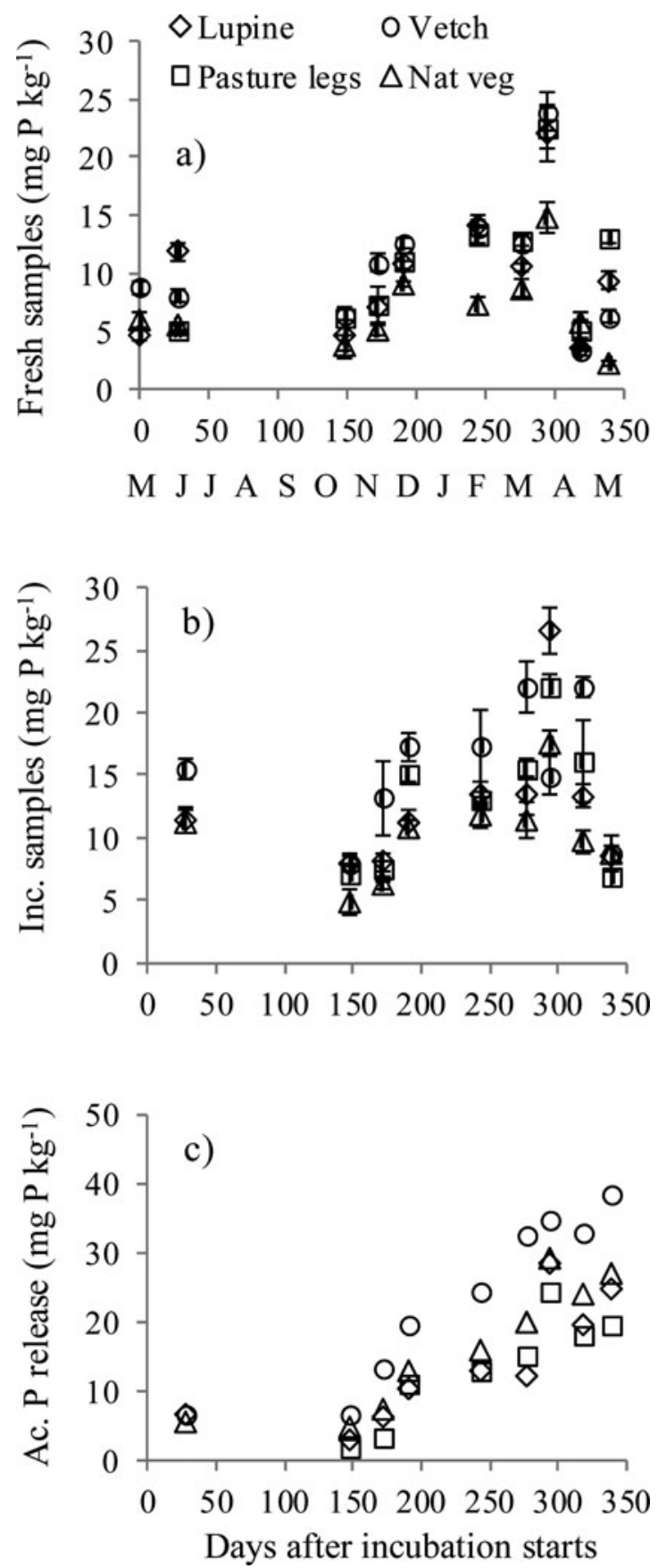

FIGURE 4 Extractable $\mathrm{P}$ in A) fresh and b) incubated soil cores determined by the Olsen method during the year after the growth of legume cover crops (May 2010 to May 2011) in Carrascal olive orchard and C) accumulated $P$ released throughout the incubation experiment. The vertical bars represent the mean confidence limits $(\alpha=0.05)$. 
means that legumes take up particularly more $\mathrm{P}$ than natural vegetation. However, the extent to which it can be assumed that legumes accessed sparingly soluble $\mathrm{P}$ is not clear because the amount of $\mathrm{P}$ recovered by legumes was not significantly greater than that recovered by oats. Although the majority of published work has emphasized the high adaptability of some legume species, including white lupine, to low-P environments (Braum and Helmke, 1995; Uhde-Stone et al., 2003; Schulze et al., 2006; Tomasi et al., 2008), in this study white lupine and the other legume species displayed only modest results in the utilization of $\mathrm{P}$ from the soil. Indeed, other authors have experienced some inability to demonstrate the efficiency of white lupine in $\mathrm{P}$ acquisition from sparingly soluble aluminium phosphate $\left(\mathrm{AlPO}_{4}\right)$ (Wang et al., 2010, 2011). Probably the mobilization of $\mathrm{P}$ depends on what the major $\mathrm{P}$ pools in the soil are. This study also showed that the adaptation of white lupine to low-P environments could at least be partially due to a high internal $\mathrm{P}$ use efficiency, with its metabolism functioning with a low tissue $\mathrm{P}$ concentration.

The DM yield of turnip grown in the micro-plots was higher when established on the mulched residues of the legume cover crops than on that of natural vegetation. The primary reason could be the increase in available $\mathrm{N}$ after the mineralization of cover crop residues. However, $\mathrm{P}$ concentration in turnip tissues was also slightly higher in the plants from the legume plots than that from the natural vegetation plots. A similar trend was observed in the barley plots. This may mean that soil $\mathrm{P}$ availability increased due to the presence of legume cover crops. In agreement with this thesis, Nuruzzaman et al. (2005a, 2005b) showed that a group of investigated legumes (Lupinus albus, Pisum sativum, and Vicia faba) enhanced the growth, tissue $\mathrm{P}$ concentration and shoot $\mathrm{P}$ content of the subsequently grown wheat, when compared with wheat grown after wheat in a soil of sufficient amount of $\mathrm{N}$ to suppress nodulation and $\mathrm{N}_{2}$ fixation. Eichler-Löbermann et al. (2009) found also that lacy phacelia (Phacelia tanacetifolia), used as green fertilization, contributed to $\mathrm{P}$ supply and $\mathrm{P}$ nutrition in succeeding main crops. The results obtained in our experiments can thus be explained as the direct effect of the legume species on the rhizosphere that, due to the exudation of organic acids, solubilized $\mathrm{P}$ that was used by the other species and/or through the mineralization of the legume cover crop residues with a higher $\mathrm{P}$ content which would become available to the succeeding crops.

The $\mathrm{P}$ nutritional status of the olive trees also supported the thesis that soil available $\mathrm{P}$ increased, albeit modestly, with the presence of legume cover crops. Hairy vetch, the cover crop that recovered more P, seems to have had a positive effect on the $\mathrm{P}$ nutritional status of trees. The pasture legumes did not have a significant effect on the $\mathrm{P}$ status of trees in the short-term, due to the lower $\mathrm{P}$ content in the first cut in comparison with white lupine and vetch. However, in the long-term, their effect on $\mathrm{P}$ status of trees increased probably due to the cumulative effect of two consecutive growing 
cycles since these species self-reseeded in the second year, whereas white lupine and hairy vetch did not. The slight but positive effect of legume cover crops (hairy vetch and pasture legumes) on tree $\mathrm{P}$ nutritional status may be the result of the combined effect of the legume species on the rizosphere during their growth cycles and the mineralization of the residues of cover crops in the succeeding growing season. In agreement with this thesis, there are published data reporting beneficial effects on companion species in mixed cultures of legumes and non-legumes ( $\mathrm{Cu}$ et al., 2005) and also on succeeding crops in a crop rotation (Nuruzzaman et al., 2005a, 2005b, 2006). However, there are also published data where the presence of legume species (Vicia faba and Lupinus albus) did not result in increased growth of the intercropping species (Zea mays), suggesting that legumes did not increase $\mathrm{P}$ availability to maize in an acidic soil (Li et al., 2010).

The incubation technique showed an increase in extractable $\mathrm{P}$ determined by the Olsen method in the plots of hairy vetch (Carrascal) and lupine (Suçães). Using the Égner-Riehm method, the differences among ground-cover treatments in Suçães were not clear, but in Carrascal, the extractable $\mathrm{P}$ was higher in lupine and hairy vetch plots in comparison with the other treatments. Unequivocally, the positive effect of legume cover crops on soil $\mathrm{P}$ availability seemed clear from the incubation technique and emphasizes the results on $\mathrm{P}$ uptake by herbaceous vegetation and olive tree $\mathrm{P}$ nutritional status. Since the incubation technique was carried out in the year following the growth of the cover crops, the increase in soil $\mathrm{P}$ availability detected in these experiments would most probably be due to $\mathrm{P}$ release from the mineralization of cover crop residues. In spite of small differences being detected between the Égner-Riehm and Olsen methods, the general pattern was similar. This observation agreed with the results of Otabbong et al. (2009), who concluded that a data set consisting of P (Égner-Riehm) could be converted into $\mathrm{P}$ (Olsen) and vice-versa with reasonably high accuracy when accounting for clay content and $\mathrm{pH}$. The effect of legumes on the increase in $\mathrm{P}$ mobilization would not be so clear as that recorded in other studies, in particular to white lupine. This may be due to the fact that these soils could not be really be considered low enough in P. On average, from the results of Égner-Riehm method, the soil of Suçães would be classified as medium in $\mathrm{P}$ and the results of Carrascal between medium and high in $\mathrm{P}$. Using the Olsen method and the critical values of $16-18 \mathrm{mg} \mathrm{P} \mathrm{kg}^{-1}$ estimated by Yang et al. (2002) to Montana soils, the soil of Suçães appear below the critical level, but part of the Carrascal results fall above the critical values.

\section{CONCLUSIONS}

All methodological approaches ( $\mathrm{P}$ content in legume cover crops, $\mathrm{P}$ uptake from soil, $\mathrm{P}$ bioindicator plants, olive tree $\mathrm{P}$ nutritional status, and soil 
available $\mathrm{P}$ from the $i n$ situ incubation) indicate an increase, albeit sometimes modest, in the soil available $\mathrm{P}$ due to the cultivation of legume species as cover crops. The increase of $\mathrm{P}$ mobilized from the soil might be due to the effects of legume cover crops in the rhizosphere during their growing cycles or thereafter during the mineralization of their high P-content residues. The higher $\mathrm{P}$ released from the hairy vetch plot, the species with the higher $\mathrm{P}$ content, in the year after the growth of the legume species, in comparison with white lupine, seem to emphasize the second hypothesis.

White lupine did not display any particular ability to mobilize $\mathrm{P}$ in these soils in comparison with the other legume cover crops, in particular hairy vetch. The great advantage of legumes might be their capability of growth in these low fertility soils, due to their access to atmospheric $\mathrm{N}_{2}$, which increased DM yield and consequently $\mathrm{P}$ content in their tissues. These results also seemed to indicate that the adaptation of white lupine to low $\mathrm{P}$ environments might be partially due to its high internal $\mathrm{P}$ use efficiency, capable of producing high dry matter yields with low $\mathrm{P}$ concentrations in their tissues.

\section{ACKNOWLEDGMENT}

The authors thank Rita Diz and Ana Pinto for laboratorial assistance.

\section{FUNDING}

Supported by FEDER funds through the Operational Program for Competitiveness Factors - COMPETE, and national funds through FCT Foundation on Science and Technology under the project PTDC/AGR$\mathrm{AAM} / 098326 / 2008$.

\section{REFERENCES}

Batjes, N. H. 1997. A world data set of derived soil properties by FAO/UNESCO soil unit for global modeling. Soil Use and Management 13: 9-16.

Bolland, M. D. A. 1997. Comparative phosphorus requirement of four lupin species. Journal of Plant Nutrition 20: 1239-1253.

Braum, S. M., and P. A. Helmke. 1995. White lupin utilizes soil phosphorus that is unavailable to soybean. Plant and Soil 176: 95-100.

Carranca, C., M. O. Torres, and J. Baeta. 2009. White lupine as a beneficial crop in Southern Europe. II. Nitrogen recovery in a legume-oat rotation and a continuous oat-oat. European Journal of Agronomy 31: 190-194.

Cu, S. T. T, J. Hutson, and K. A. Schuller. 2005. Mixed culture of wheat (Triticum aestivum L.) with white lupin (Lupinus albus L.) improves the growth and phosphorus nutrition of the wheat. Plant and Soil 272: 143-151.

Duran, J., J. L. Morse, and P. M. Groffman. 2012. Comparison of in situ methods to measure N mineralization rates in forest soils. Soil Biology and Biochemistry 46: 145-147.

Égner, H., H. Riehm, and W. R. Domingo. 1960. Untersuchungen uber die chemische bodeananalyse als Grundlage due die Beurteilung des Nahrstoffzustandes der Boden II. Chemise Extraktionsmethoden zur Phosphor-und Kaliumbestimmung Kungl [Studies on the chemical analysis of the soil to 
assess the nutrient status of the soil II. Chemical extraction methods for phosphorus and potassium determination]. Lantbrushoegsk Ann 26: 199-215.

Eichler-Lobermann, B., R. Gaj, and E. Schnug. 2009. Improvement of soil phosphorus availability by green fertilization with catch crops. Communications in Soil Science and Plant Analysis 40: 70-81.

Gilbert, N. 2009. The disappearing nutrient. Nature 461: 716-718.

Gilliam, J. W., T. J. Logan, and F. E. Broadbent. 1985. Fertilizers use in relation to the environment. In: Fertilizer Technology and Use, ed O. P. Engelstad, pp. 561-588. Madison, WI: SSSA.

Havlin, J. L., J. D. Beaton, S. L. Tisdale, and W. L. Nelson. 2005. Soil Fertility and Fertilizers: An Introduction to Nutrient Management. Upper Saddle River, NJ: Pearson Prentice Hall.

Hawkesford, M., W. Horst, T. Kichey, H. Lambers, J. Schjoerring, I. S. Moller, and P. White. 2012. Function of macronutrients. In: Marschner's Mineral Nutrition of Higher Plants, ed. P. Marschner, pp. 135-189. London, UK: Elsevier.

Jarrell, W. M., and R. B. Beverly. 1981. The dilution effect in plant nutrition studies. Advances in Agronomy 34: 197-224.

Jensen, C. R., B. Joernsgaard, M. N. Andersen, J. L. Christiansen, V. O. Mogensen, P. Friis, and C. T. Petersen. 2004. The effect of lupines as compared with peas and oats on the yield of the subsequent winter barley crop. European Journal of Agronomy 20: 405-418.

Le Bayon, R. C., L. Weisskopf, E. Martinoia, J. Jansa, E. Frossard, F. Keller, K. B. Follmi, and J.-M. Gobat. 2006. Soil phosphorus uptake by continuously cropped Lupinus albus: A new microcosm design. Plant and Soil 283: 309-321.

Ledgard, S. F. 1991. Tranfer of fixed nitrogen from white clover to associated grasses in swards grazed by dairy cows, estimated using 15N methods. Plant and Soil 131: 215-223.

Li, H., J. Shen, F. Zhang, P. Marschner, G. Cawthray, Z. Rengel. 2010. Phosphorus uptake and rhizosphere properties of intercropped and monocropped maize, faba bean, and white lupin in acidic soil. Biology and Fertility of Soils 46: 79-91.

Nuruzzaman, M., H. Lambers, M. D. A. Bolland, and E. J. Veneklaas. 2005a. Phosphorus uptake by grain legumes and subsequently grown wheat at different levels of residual phosphorus fertiliser. Australian Journal of Agricultural Research 56: 1041-1046.

Nuruzzaman, M., H. Lambers, M. D. A. Bolland, and E. J. Veneklaas. 2005b. Phosphorus benefits of different legume crops to subsequent wheat grown in different soils of Western Australia. Plant and Soil 271: 175-187.

Nuruzzaman, M., H. Lambers, M. D. A. Bolland, and E. J. Veneklaas. 2006. Distribution of carboxylates and acid phosphatase and depletion of different phosphorus fractions in the rhizosphere of a cereal and three grain legumes. Plant and Soil 281: 109-120.

Olsen, S. R., G. V. Cole, F. S. Watanabe, and L. A. Dean. 1954. Estimation of available phosphorus in soils by extraction with sodium bicarbonate. U.S. Department of Agriculture, Circular 939. Washington, DC: U.S. Government Printing Office.

Otabbong, E., K. Borling, T. Katterer, and L. Mattsson. 2009. Compatibility of the ammonium lactate (AL) and sodium bicarbonate (Olsen) methods for determining available phosphorus in Swedish soils. Acta Agriculturae Scandinavica, Section B 59: 373-378.

Ott, R. L., and M. Longnecker. 2001. An Introduction to Statistical Methods and Data Analysis. Pacific Grove, CA: Duxbury.

Raison, R. J., M. J. Connell, and P. K. Khanna. 1987. Methodology for studying fluxes of soil mineral-N in situ. Soil Biology and Biochemistry 19: 521-530.

Rodrigues, M. A., V. Gomes, L. G. Dias, J. Pires, C. F. Aguiar, and M. Arrobas. 2010. Evaluation of soil nitrogen availability by growing tufts of nitrophilic species in an intensively grazed biodiverse legume-rich pasture. Spanish Journal of Agricultural Research 8: 1058-1067.

Romheld, V. 2012. Diagnosis of deficiency and toxicity of nutrients. In: Marschner's Mineral Nutrition of Higher Plants, ed. P. Marschner, Pp. 299-312. London: Elsevier.

Schulze, J., G. Temple, S. J. Temple, H. Beschow, and C. P. Vance. 2006. Nitrogen fixation by white lupin under phosphorus deficiency. Annales Botanici 98: 731-740.

Sepehr, E., Z. Rengel, E. Fateh, and M. R. Sadaghiani. 2012. Differential capacity of wheat cultivars and white lupin to acquire phosphorus from rock phosphate, phytate and soluble phosphorus sources. Journal of Plant Nutrition 35: 1180-1191. 
Subler, S., R. W. Parmelee, and M. F. Allen. 1995. Comparison of buried bag and PVC core methods for in situ measurements of nitrogen mineralization rates in an agricultural soil. Communications in Soil Science and Plant Analysis 26: 2369-2381.

Tomasi, N., L. Weisskopf, G. Renella, L. Landi, R. Pinton, Z. Varanini, P. Nannipieri, J. Torrent, E. Martinoia, and S. Cesco. 2008. Flavonoids of white lupin roots participate in phosphorus mobilization from soil. Soil Biology and Biochemistry 40: 1971-1974.

Uhde-Stone, C., G. Gilbert, J. M.-F. Johnson, R. Litjens, K. E. Zinn, S. J. Temple, C. P. Vance, and D. L. Allan. 2003. Aclimation of white lupin to phosphorus deficiency involves enhanced expression of genes related to organic acid metabolism. Plant and Soil 248: 99-116.

Varennes, A. de, M. O. Torres, C. Cunha-Queda, M. J. Goss, and C. Carranca. 2007. Nitrogen conservation in soil and crop residues as affected by crop rotation and soil disturbance under Mediterranean conditions. Biology and Fertility of Soils 44: 49-58.

Veneklaas, E. J., J. Stevens, G. R. Cawthray, S. Turner, A. M. Grigg, and H. Lambers. 2003. Chickpea and white lupin rhizosphere carboxylates vary with soil properties and enhance phosphorus uptake. Plant and Soil 248: 187-197.

Walinga, I., W. van Vark, V. J. G. Houba, and J. J. van der Lee. 1997. Soil and plant analysis. Part 7 Plant Analysis Procedures. Wageningen, the Netherlands: Department of Soil Science and Plant Nutrition, Wageningen Agricultural University.

Walley, F. L., G. O. Tomm, A. Matus, A. E. Slinkard, and C. van Kessel. 1996. Allocation and cycling of nitrogen in an alfalfa-bromegrass sward. Agronomy Journal 88: 834-843.

Wang, X., C. N. Guppy, L. Watson, P. W. S. Sale, and C. Tang. 2011. Availability of sparingly soluble phosphorus sources to cotton (Gossypium hirsutum L.), wheat (Triticum aestivum L.) and white lupin (Lupinus albus $L$.) with different forms of nitrogen as evaluated by a $32 \mathrm{P}$ isotopic dilution technique. Plant and Soil 348: 85-98.

Wang, X., C. Tang, C. N. Guppy, and P. W. G. Sale. 2010. Cotton, wheat and white lupin differ in phosphorus acquisition from sparingly soluble sources. Environmental and Experimental Botany 69: 267-272.

Watt, M., and J. R. Evans. 2003. Phosphorus acquisition from soil by white lupin (Lupinus albus L.) and soybean (Glycine max L.), species with contrasting root development. Plant and Soil 248: 271-283.

Werner, W. 2010. Ulmann's Agrochemicals, Fertilizers, 3 (Chap. 9.1 and 9.2), pp. 99-111. Weinheim, Germany: Wiley-VCH Verlag GmbH \& Co.

Yang, J. E., C. A. Jones, H. J. Kim, and J. S. Jacobsen. 2002. Soil inorganic phosphorus fractions and Olsen-P in phosphorus-responsive calcareous soils: Effects of fertilizer amount and incubation time. Communications in Soil Science and Plant Analysis 33: 855-871.

Zhu, Y., F. Yan, C. Zorb, and S. Schubert. 2005. A link between citrate and proton release by proteoid roots of white lupin (Lupinus albus L.) grown under phosphorus-deficient conditions? Plant Cell Physiology 46: 892-901. 